\title{
Estimation of Radiological Hazards of Some Egyptian Building Materials Due to Natural Radioactivity
}

\author{
M. A. M. Uosif \\ Physics Department, Faculty of Science, Al-Azhar University, Assiut Branch, \\ 71524 Assiut, Egypt \\ Corresponding author:e-mail:Dr_Mohamed_Amin@Lycos.com \\ Physics Department, Faculty of Science, Al-Azhar University, Assiut Branch, \\ 71524 Assiut, Egypt. \\ Fax: $\quad+20882181436-$ Mobil Tel.: +20/111/7058707
}

\begin{abstract}
Concentrations of natural radionuclides $(226 \mathrm{Ra}, 232 \mathrm{Th}$ and $40 \mathrm{~K})$ content and its radiological hazards were presented in this paper for variety of commonly used building materials soil, sand, redbrick, clay brick, limestone and cement. Measurements were done by using gamma spectrometry (NaI (Tl) 3"x 3"). The radiation hazard indices like: Radium equivalent (Raeq), external hazard index (Hex), activity concentration index (Iex), the specific dose rates in door $(D)$, and the annual effective dose $(D E)$ due to gamma radiation were calculated and compared with internationally recommended values.
\end{abstract}

Keywords: Building materials; Activity concentration index; Dose rate; Annual effective dose

\section{Introduction}

The exposure of human beings to ionizing radiation from natural sources is a continuing and inescapable feature of life on earth. There are two main contributors to natural radiation exposures: high-energy cosmic ray particles incident on the earth's atmosphere and radioactive nuclides that originated in the earth's crust and are present everywhere in the environment, including the human body itself.

Building materials containing naturally occurring radionuclides are the main source of exposure. The knowledge of natural radioactivity in these materials is then important for determining the amount of public exposure because people spend most of their time (about 80\%) indoors (Stoulos et al., 2003)[1]. Furthermore, knowledge of this radioactivity is useful in setting the standards and national guidelines in regard to the international recommendations and in assessing the associated radiation hazard.

The population-weighted average of indoor absorbed dose rate in air from terrestrial sources of radioactivity is estimated to be $84 \mathrm{nGy} \mathrm{h}^{-1}$ (UNSCEAR, 2000)[2]. Elevated indoor external dose rates may arise from high activities of radionuclides in building materials. Large-scale surveys of concentrations of radioisotopes in construction materials were summarized by the United Nations Scientific Committee on the Effects of Atomic Radiation (UNSCEAR, 1977)[3]. Consequently, this study comes within the framework of the estimation of the possible radiological hazards resulting from the natural radiation, which can be exposed to the Egyptian population when they use of such building materials. 


\section{Materials and Methods}

\subsection{Sample Description and Preparation}

A total of 39 samples of 6 different buildings materials (soil, sand, clay brick, limestone, gypsum and cement) were collected for the measurements of activity concentrations from Assiut, Qena and Souhag governments in Upper Egypt. The materials were obtained from suppliers or gathered directly in demolished houses or buildings under construction.

A brief description of these building materials follows:

- Soil is a mixture of mineral and organic matter, it is mainly made up of oxygen $(46.7 \%)$, silicon $(27 \%)$, aluminum $(8.1 \%)$ and iron $(5.0 \%)$. Plant nutrients like $\mathrm{Ca}, \mathrm{Mg}, \mathrm{K}, \mathrm{Na}, \mathrm{P}$ and $\mathrm{S}$ are present in the minerals and in the soil solution. $\mathrm{O}_{2}, \mathrm{Si}$, and $\mathrm{Al}$ occur as constituents of minerals and as oxides. $\mathrm{Fe}$ occurs mainly in the form of oxides and ferromagnesian minerals. Ca occurs mainly in calcite, gypsum, apatite and dolomite. $\mathrm{Mg}$ is present mainly in dolomite and hornblend. $\mathrm{K}$ occurs mainly in microcline and mica. $\mathrm{P}$ occurs as aluminum phosphate and calcium phosphate and in the organic form as phospholipids, inositol, choline, etc. $\mathrm{N}$ occurs mainly in the organic form as proteins, amino acids, etc. All micronutrients like $\mathrm{Mo}, \mathrm{Fe}, \mathrm{Mn}, \mathrm{Zn}, \mathrm{Cu}, \mathrm{B}$ occur in the inorganic form that is capable of supporting plant growth

- Sand is a granular material made up of fine rock particles. The most common constituent of sand is silica (silicon dioxide, or $\mathrm{SiO} 2$ ), usually in the form of quartz. The composition of sand varies according to local rock sources and conditions. Bricks may be made from clay, shale, soft slate, and calcium silicate.

- Brick clay, its chemical composition is as follows:

-Silica $(55 \%)$, it is present in brick clay as the chemical composition of alumina and forming silicate of alumina. Sometimes silica is present in pure form termed as flint. Silica prevents shrinking, cracking and warping of brick clay.

-Alumina(30\%): it imparts plasticity to brick clay which is very important in molding. It also imparts density.

-Iron oxide $(\mathbf{8 \%})$ : The presence of iron oxide increases impermeability and durability of brick. The color of brick depend upon iron oxide and color changes from light yellow to orange and red as iron oxide goes up to $8 \%$. -Magnesia(5\%): Presence of small quantity of magnesia decreases shrinkage and gives yellowish tint.

-Lime(1\%): Lime melts silica in burning and binds the particles of brick together. It also reduces the shrinkage of brick during drying. Excess of lime cause the brick to fuse and shape will be lost. -Alkali and Organic Matter(1\%): Small quantity assist burning of brick clay. It also reduces the fusion point. If excess amount is present and not burned properly the brick would be porous.

- Limestone is a sedimentary rock composed largely of the minerals calcite and aragonite, which are different crystal forms of calcium carbonate (CaCO3). Many limestones are composed from skeletal fragments of marine organisms such as coral or foraminifera. Limestone makes up about $10 \%$ of the total volume of all sedimentary rocks. It is made from the mineral calcite, which comes from the beds of evaporated seas and lakes and from seashells. 
- Gypsum is a very soft sulfate mineral composed of calcium sulfate dihydrate, with the chemical formula CaSO4.2H2O. It can be used as a fertilizer, is the main constituent in many forms of plaster and is widely mined. A much harder and very fine-grained white or lightly tinted variety of gypsum, called alabaster, has been used for sculpture by many cultures including Ancient Egypt and Ancient Rome. Gypsum is moderately water-soluble ( 2.0-2.5 g/l at $25^{\circ} \mathrm{C}$ ) and, in contrast to most other salts, it exhibits a retrograde solubility, becoming less soluble at higher temperatures. When gypsum is heated in air it loses water and converts first to calcium sulfate hemihydrate, (bassanite, often simply called "plaster") and, if heated further, to anhydrous calcium sulfate (anhydrite). As for anhydrite, its solubility in saline solutions and in brines is also strongly dependent on $\mathrm{NaCl}$ concentration (Smith Joshua, 2007) [4].

- Cement is a mixture of compounds made by burning limestone and clay together at very high temperatures ranging from 1400 to 1600 . The chemical composition of cement is Tricalcium silicate $3 \mathrm{CaO} \cdot \mathrm{SiO}_{2}(50-70 \%)$, Dicalcium silicate $2 \mathrm{CaO} \cdot \mathrm{SiO}_{2}(15-30 \%)$, Tricalcium aluminate $3 \mathrm{CaO} \cdot \mathrm{Al} 2 \mathrm{O} 3$ $(5-10 \%)$,Tetra calcium aluminoferrite $4 \mathrm{CaO} \cdot \mathrm{Al}_{2} \mathrm{O}_{3} \cdot \mathrm{Fe}_{2} \mathrm{O}_{3}(5-15 \%)$ and Calcium sulfate dehydrate $\mathrm{CaSO} 4 \cdot 2 \mathrm{H} 2 \mathrm{O} \sim 5 \%$.

Each sample under investigation was dried in an oven at about $110{ }^{\circ} \mathrm{C}$ to ensure that moisture was completely removed. The samples were crushed, homogenized and sieved through a $200 \mu \mathrm{m}$, which is the optimum size enriched in heavy minerals. Weighed samples were placed in polyethylene beaker, of $350-\mathrm{cm}^{3}$ volumes each. The beakers were completely sealed for 4 weeks to reach secular equilibrium where the rate of decay of the progeny becomes equal to that of the parent (radium and thorium) $[5,6]$ within the volume and the progeny will also remain in the sample.

\subsection{Instrumentation and Calibration}

Activity measurements were performed by gamma ray spectrometer, employing a scintillation detector (3" x 3"). It is hermetically sealed assembly, which includes a $\mathrm{NaI}(\mathrm{Tl})$ crystal, coupled to PC-MCA Canberra Accuspes. To reduce gamma ray background, a cylindrical lead shield (100 mm thick) with a fixed bottom and movable cover shielded the detector. The lead shield contained an inner concentric cylinder of copper ( $0.3 \mathrm{~mm}$ thick) in order to absorb X-rays generated in the lead. In order to determine the background distribution in the environment around the detector, an empty sealed beaker was counted in the same manner and in the same geometry as the samples. The measurement time of activity or background was 43200s. The background spectra were used to correct the net peak area of gamma rays of measured isotopes. A dedicated software program Genie 2000[7] from Canberra has carried out the online analysis of each measured gamma ray spectrum.

The efficiency calibration curve was made using different energy peaks covering the range up to $\approx 2000 \mathrm{keV}$. Measurements were performed with calibrated source samples, which contain a known activity of one or more gamma ray emitters of the radionuclides ${ }^{60} \mathrm{Co}(1173.2$ and $1332.5 \mathrm{keV}),{ }^{133} \mathrm{Ba}(356.1 \mathrm{keV}),{ }^{137} \mathrm{Cs}(661.9 \mathrm{keV})$ and ${ }^{226} \mathrm{Ra}(1764.49$ $\mathrm{keV}$ ), with certified accuracies of $\approx 2 \%$, Equation (1) is used for calculating the absolute efficiency:

$$
E f f=\frac{100 \cdot N_{p}}{I_{\gamma} \cdot T O C \cdot A_{B O C}}
$$

Where, $\mathrm{Np}$ the net peak area at $\mathrm{E}_{\gamma}, \mathrm{I}_{\gamma}$ the intensity of emitted gamma ray, TOC the time of counting and $\mathrm{A}_{\mathrm{BOC}}$ the activity of the standard source at beginning of counting (BOC). $\mathrm{A}_{\mathrm{BOC}}$ was calculated by equation (2) 


$$
A_{B O C}=A_{D O C} \cdot \exp (-\lambda \cdot(B O C-D O C))
$$

Where $A_{D O C}$ is the activity of the standard source at date of calibration $D O C$, and $\lambda$ is the decay constant.

Daily efficiency and energy calibrations for each sample measurement were carried out to maintain the quality of the measurements. The absolute efficiency of the detector was calculated at the specific energy of the standard sources for the same geometry of the samples. But, the gamma spectra of the samples have different gamma energies. So, some fitting function is needed to calculate the absolute efficiency for any considered gamma energy. A function [8] is used, for this purpose, for calculating the absolute efficiency at any gamma energy of interest in the energy range below $2000 \mathrm{keV}$, which is in the following form:

$$
\eta=a-b \times \exp \left(-c \times E_{\gamma}^{d}\right)
$$

Where, E $\gamma$ represents energy in $\mathrm{MeV}$, where $\mathrm{a}, \mathrm{b}, \mathrm{c}$ and $\mathrm{d}$ are coefficient data. By equation (3), the absolute efficiency, $\eta$, can be determined at any specific energy $E \gamma$, if the energies and the coefficient data are known. From the experimental efficiency curves, the coefficient data were determined, by using the curve-fitting program Curve Expert $1.34[9]$.

\subsubsection{Uncertainty of Efficiency}

The combined standard uncertainty of absolute efficiency $u(E F F)$ consists of $u\left(N_{p}\right)$, $u\left(I_{\gamma}\right), u(T O C)$ and $u\left(A_{B O C}\right)$ so,

$$
\left\lceil\frac{u(E F F)}{E F F}\right\rfloor^{2}=\left\lfloor\frac{u\left(N_{p}\right)}{N_{p}}\right]^{2}+\left\lfloor\frac{u\left(I_{\gamma}\right)}{I_{\gamma}}\right]^{2}+\left[\frac{u(T O C)}{T O C}\right]^{2}+\left[\frac{u\left(A_{B O C}\right)}{A_{B O C}}\right]^{2}
$$

Because $u(T O C) \ll T O C$, we neglected $u(T O C)$. The value of $u\left(A_{B O C}\right)$ was calculated by equ. (5)

$$
\left[\frac{u\left(A_{B O C}\right)}{A_{B O C}}\right]^{2}=\left[\frac{u\left(A_{D O C}\right)}{A_{D O C}}\right]^{2}+(B O C-D O C)^{2} \cdot u^{2}(\lambda)
$$

We got $u\left(N_{p}\right)$ from the code Genie 2000, while $u(\lambda)$ and $u\left(\mathrm{I}_{\gamma}\right)$ were taken from the compilation of Reus and Westmeier [10]. The calibration standards used had a certified accuracy of $\leq 2 \%$. By measurements for many times it could be verified with a total uncertainty of the full-energy-peak efficiency of $5 \%$.

\subsubsection{Calculation of Activity}

Calculations of count rates for each detected photo peak and radiological concentrations (activity per mass unit or specific activity) of detected radionuclides depend on the establishment of secular equilibrium in the samples. The ${ }^{232} \mathrm{Th}$ concentration was determined from the average concentrations of ${ }^{212} \mathrm{~Pb}(238.6 \mathrm{keV})$ and ${ }^{228} \mathrm{Ac}(911.1 \mathrm{keV})$ in the samples, and that of ${ }^{226} \mathrm{Ra}$ was determined from the average concentrations of the ${ }^{214} \mathrm{~Pb}(351.9 \mathrm{keV})$ and ${ }^{214} \mathrm{Bi}(609.3$ and $1764.5 \mathrm{keV})$ decay products[11]. The activity concentration in $\mathrm{Bqkg}^{-1}(\mathrm{~A})$ in the environmental samples was obtained as follows:

$$
A=\frac{N_{\mathrm{p}}}{e \times \eta \times m}
$$


Where $N_{p}=$ the (cps) sample - (cps) B.G, $e$ is the abundance of the $\gamma$-line in a radionuclide, $\eta$ is the measured efficiency for each gamma-line observed for the same number of channels either for the sample or the calibration source, and $m$ the mass of the sample in kilograms. The uncertainty of activity $u(A)$ was calculated by the following equation:

$$
u(A)=A \sqrt{\left[u\left(N_{p}\right) /\left(N_{p}\right)\right]^{2}+[u(\eta) /(\eta)]^{2}+[u(m) /(m)]^{2}}
$$

From the equation, we can find that, there are many sources of uncertainties of the Activity and some may result in considerable uncertainties. The following sources of uncertainties were considered:

\subsubsection{Uncertainty of the Determination of Net Peak Areas}

The uncertainty of each single net-peak area is determined by the spectrum-evaluation code. It takes into account the Poisson uncertainties of the counts in the individual channels as well as the uncertainty of the background determination. Sometimes a peak cannot be attributed unambiguously to a single nuclide. If it seems that the contributions of other nuclides to a peak are very small no correction was applied. Due to this procedure we think that we have to assume a maximum inaccuracy of $2 \%$ due to contributions of other nuclides but it must be pointed out that in the average this uncertainty should be smaller. By repeated measurements it could be verified that the total uncertainty of the efficiency calibration was $5 \%$.

\section{Results and Discussion}

\subsection{Activity Cncentrations}

This study is a continuation of our ongoing project in physics department (faculty of science, Al-Azher university, Assuit branch, Egypt) related to the measurement of specific activity of ${ }^{226} \mathrm{Ra},{ }^{232} \mathrm{Th}$ and ${ }^{40} \mathrm{~K}$ in environmental samples from Upper Egypt using a gamma-ray spectrometric technique and estimation of the gamma dose rate from these radionuclides. The results of analysis of activity concentration of ${ }^{226} \mathrm{Ra},{ }^{232} \mathrm{Th}$ and ${ }^{40} \mathrm{~K}$ in controlled samples of building materials are presented in Table 1. Activity is reported in $\mathrm{Bqkg}^{-1}$ on the basis of the sample's dry weight.

Table 1. Activity Concentrations of ${ }^{226} \mathrm{Ra},{ }^{232} \mathrm{Th}$ and ${ }^{40} \mathrm{~K}$ in Different Samples

\begin{tabular}{|c|c|c|c|}
\hline $\begin{array}{c}\text { Sample } \\
\text { Name }\end{array}$ & $\begin{array}{c}{ }^{226} \mathrm{Ra} \\
\mathrm{Ain}(\mathrm{Bq} \mathrm{kg}\end{array}$ & $\begin{array}{c}{ }^{232} \mathrm{Th} \\
\mathrm{A} \text { in }(\mathrm{Bq} \mathrm{kg}\end{array}$ & $\begin{array}{c}{ }^{40} \mathrm{~K} \\
\mathrm{~A} \text { in }(\mathrm{Bq} \mathrm{kg}\end{array}$ \\
\hline Soil(Assiut) & $39.7 \pm 2.0$ & $56.9 \pm 2.8$ & $196.4 \pm 9.8$ \\
\hline Soil(Assiut) & $31.2 \pm 1.6$ & $51.7 \pm 2.6$ & $149 \pm 7.4$ \\
\hline Soil(Assiut) & $35.3 \pm 1.8$ & $53.3 \pm 2.7$ & $210.3 \pm 10.5$ \\
\hline Soil(Qena) & $37.5 \pm 1.9$ & $71.3 \pm 4.1$ & $239.9 \pm 12$ \\
\hline Soil(Qena) & $32.5 \pm 1.4$ & $59.3 \pm 2.1$ & $233.2 \pm 11$ \\
\hline Soil(Souhag) & $29 \pm 1.1$ & $67.3 \pm 3.9$ & $219.6 \pm 9$ \\
\hline Soil(Souhag) & $37.5 \pm 1.9$ & $61.3 \pm 3.1$ & $237.9 \pm 12$ \\
\hline Average & $\mathbf{3 4 . 6} \pm \mathbf{1 . 7}$ & $\mathbf{6 0 . 2 \pm 3}$ & $\mathbf{2 1 2 . 3 \pm 1 0 . 3}$ \\
\hline Range of values & $\mathbf{2 9 - 3 9 . 7}$ & $\mathbf{5 1 . 7 - 7 1 . 3}$ & $\mathbf{1 4 9 - 2 3 9 . 9}$ \\
\hline Sand(Assiut) & $16.5 \pm 0.8$ & $17.4 \pm 0.9$ & $144 \pm 7.2$ \\
\hline Sand(Assiut) & $17.7 \pm 0.9$ & $18.4 \pm 0.9$ & $124 \pm 7.2$ \\
\hline
\end{tabular}




\begin{tabular}{|c|c|c|c|}
\hline Sand (Qena) & $28.7 \pm 1.4$ & $29 \pm 1.6$ & $155.4 \pm 8.8$ \\
\hline Sand (Qena) & $23.5 \pm 0.8$ & $31.3 \pm 0.9$ & $164 \pm 7.8$ \\
\hline Sand(Souhag) & $19.5 \pm 0.9$ & $17.9 \pm 1$ & $140 \pm 6.2$ \\
\hline Sand(Souhag) & $18.7 \pm 1.2$ & $21 \pm 3.5$ & $165.4 \pm 9$ \\
\hline Average & $20.8 \pm 1$ & $22.5 \pm 1.2$ & $148.8 \pm 13.3$ \\
\hline Range of values & $16.5-28.7$ & $17.4-31.3$ & $124-165.4$ \\
\hline Clay brick (Assiut) & $54.3 \pm 2.7$ & $65.3 \pm 3.3$ & $285.4 \pm 14.3$ \\
\hline Clay brick (Assiut) & $65 \pm 3.3$ & $78.1 \pm 3.9$ & $352.1 \pm 17.6$ \\
\hline Clay brick (Qena) & $59.6 \pm 3$ & $80.6 \pm 4$ & $375.5 \pm 18.8$ \\
\hline Clay brick (Qena) & $36 \pm 1.8$ & $63.4 \pm 3.2$ & $216.3 \pm 108$ \\
\hline Clay brick (Qena) & $29.3 \pm 1.5$ & $35.3 \pm 1.8$ & $166.8 \pm 8.3$ \\
\hline Clay brick (Souhag) & $35.5 \pm 1.8$ & $30.3 \pm 1.5$ & $245.5 \pm 12.3$ \\
\hline Clay brick (Souhag) & $51.7 \pm 2.6$ & $89.3 \pm 4.5$ & $288.2 \pm 14.4$ \\
\hline Average & $47.3 \pm 2.4$ & $68.9 \pm 4.1$ & $275.7 \pm 12.3$ \\
\hline Range of values & 29.3-65 & $50.3-89$ & $166.8-375.5$ \\
\hline Limestone (Assiut) & $30 \pm 1.5$ & $47.2 \pm 2.4$ & $120.6 \pm 6$ \\
\hline Limestone (Assiut) & $35.3 \pm 1.8$ & $51.1 \pm 2.6$ & $125.8 \pm 6.3$ \\
\hline Limestone (Qena) & $27.1 \pm 1.4$ & $35.5 \pm 1.8$ & $114.8 \pm 5.7$ \\
\hline Limestone (Qena) & $23 \pm 2.1$ & $52 \pm 3.6$ & $74.5 \pm 5.2$ \\
\hline Limestone (Souhag) & $33.5 \pm 2$ & $45.6 \pm 3.7$ & $89.3 \pm 4.5$ \\
\hline Limestone (Souhag) & $31.6 \pm 3.2$ & $79.2 \pm 5.1$ & $81.3 \pm 3.3$ \\
\hline Average & $30.1 \pm 2$ & $51.8 \pm 3.5$ & $101.1 \pm 10.9$ \\
\hline Range of values & $23-35.3$ & $35.5-79.2$ & $74.5-125.8$ \\
\hline Gypsum(Assiut) & $40.1 \pm 2$ & $56.1 \pm 2.8$ & $66.8 \pm 2.9$ \\
\hline Gypsum(Assiut) & $28.5 \pm 2$ & $69.2 \pm 3.5$ & $72 \pm 2.1$ \\
\hline Gypsum(Qena) & $37.6 \pm 1.9$ & $72 \pm 3.6$ & $88.2 \pm 4.1$ \\
\hline Gypsum(Qena) & $57.5 \pm 2.9$ & $69.4 \pm 3.3$ & $65.2 \pm 3.3$ \\
\hline Gypsum(Souhag) & $46.4 \pm 4.1$ & $71 \pm 5.7$ & $78.5 \pm 1.4$ \\
\hline Gypsum(Souhag) & $34.1 \pm 1.7$ & $55.1 \pm 2.8$ & $96.6 \pm 4.8$ \\
\hline Average & $40.7 \pm 2.4$ & $65.5 \pm 4.2$ & $77.9 \pm 9.6$ \\
\hline Range of values & $28.5-57.5$ & $55.1-72$ & $65.2-96.6$ \\
\hline Cement (Assiut) & $30.8 \pm 3.6$ & $66.5 \pm 3.6$ & $91.3 \pm 7.1$ \\
\hline Cement (Assiut) & $29 \pm 2.5$ & $55.2 \pm 4.8$ & $97.3 \pm 5.6$ \\
\hline Cement (Qena) & $33.5 \pm 1.7$ & $59.4 \pm 3$ & $88.9 \pm 4.7$ \\
\hline Cement (Qena) & $29.8 \pm 3.3$ & $42.6 \pm 3.6$ & $85.5 \pm 3.3$ \\
\hline Cement (Souhag) & $31.8 \pm 3.4$ & $75.2 \pm 3.2$ & $76.6 \pm 5.4$ \\
\hline Cement (Souhag) & $44.2 \pm 2.2$ & $67.7 \pm 2.4$ & $94.8 \pm 2.7$ \\
\hline Cement (Souhag) & $37.2 \pm 3.9$ & $66.1 \pm 2.7$ & $88.5 \pm 3.9$ \\
\hline Average & $33.8 \pm 3.1$ & $61.8 \pm 3.3$ & $89.0 \pm 5$ \\
\hline Range of values & $29.8-44.2$ & $42.6-75.2$ & $76.6-97.3$ \\
\hline
\end{tabular}


From the obtained results, which listed in Tble 1, large variation among the radioactivity concentration for different samples has been observed. It may be due to geological condition and the raw material that used in making the building materials under investigation. It can be seen that ${ }^{40} \mathrm{~K}$ almost always contributes to the most specific activity compared to ${ }^{226} \mathrm{Ra}$ and ${ }^{232} \mathrm{Th}$. The results tell us that for all samples under investigation, the largest average activity of ${ }^{226} \mathrm{Ra}$ is $\left(47.3 \pm 2.4 \mathrm{~Bq} \cdot \mathrm{kg}^{-1}\right)$ for clay bricks , it is more than two times greater than that of the lowest value $\left(20.8 \pm l B q . \mathrm{kg}^{-1}\right)$, which was found in sand samples. ${ }^{232} \mathrm{Th}$ is in the wide range from $\left(17.4 \pm 0.9 \mathrm{~Bq} \cdot \mathrm{kg}^{-1}\right)$ in sand (Assiut) up to $\left(80.6 \pm 4 \mathrm{~Bq} \mathrm{~kg}^{-1}\right)$ in Clay brick (Qena). Concentration of ${ }^{40} \mathrm{~K}$ values ranging from $\left(66.8 \pm 2.9 \mathrm{~Bq} \mathrm{~kg} \mathrm{~g}^{-1}\right)$ in Gypsum(Assiut) to $\left(375.5 \pm 18.8 \mathrm{~Bq} \cdot \mathrm{kg}^{-1}\right)$ in redbrick (Qena), it is approximately the maximum admissible value of $\left(370 \mathrm{~Bq} \mathrm{~kg} \mathrm{~g}^{-1}\right)$ set in the UNSCEAR report (1988)[12]. Figure 1 shows the results of Table 1 in graphical form, clearly indicating the high- and low-activity samples.

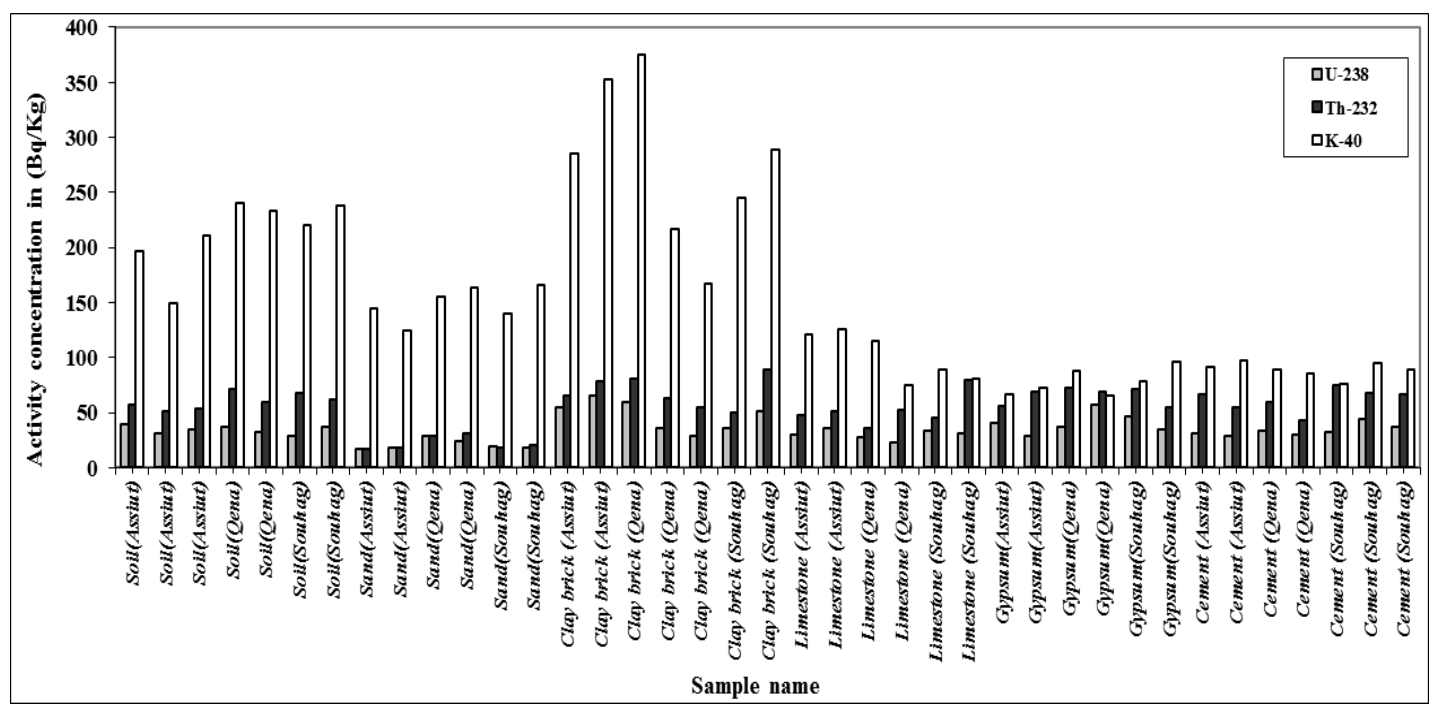

Figure 1. Activity Concentrations of the Radioelements (in Bq $\mathrm{kg}^{-1}$ ) Found in Studied Samples

\subsection{Radium Equivalent Activity}

Because of ${ }^{226} \mathrm{Ra},{ }^{232} \mathrm{Th}$ and ${ }^{40} \mathrm{~K}$ are non-uniformly distributed in building materials. In order to compare the specific activity of materials containing different amounts of ${ }^{226} \mathrm{Ra}$, ${ }^{232} \mathrm{Th}$ and ${ }^{40} \mathrm{~K}$, the radium equivalent activity $\mathrm{Ra}_{\mathrm{eq}}$ is used as defined by the following expression (Hayambu et al., 1995)[13]:

$$
R a_{e q}=A_{R a}+1.43 A_{T h}+0.077 A_{K}
$$

Where $A_{R a}, A_{T h}$ and $A_{\mathrm{K}}$ are the mean activity in $\left(\mathrm{Bq} \mathrm{kg}^{-1}\right)$ of ${ }^{226} R a,{ }^{232} \mathrm{Th}$ and ${ }^{40} \mathrm{~K}$, respectively. Eq. (8) is based on the fact that $370\left(B q \mathrm{~kg}^{-1}\right)$ of ${ }^{226} \mathrm{Ra}, 259\left(\mathrm{~Bq} \mathrm{~kg} \mathrm{~g}^{-1}\right)$ of ${ }^{232} \mathrm{Th}$ and $4810\left(B \mathrm{~kg}^{-1}\right)$ of ${ }^{40} \mathrm{~K}$, produce the same $\gamma$-ray dose equivalent. The values of $R a_{e q}$ are listed in column 2 of Table (2) for all the samples under investigation. These values ranged from $52.49 \mathrm{~Bq} \mathrm{~kg}$ in sand (Assiut) to $203.8 \mathrm{~Bq} \mathrm{~kg}^{-1}$ in Clay brick (Qena). All results are less than the maximum admissible value of $370 \mathrm{~Bq} \mathrm{~kg}^{-1}$ set in the UNSCEAR report (1988), which is equivalent to an external dose of $1.5 \mathrm{mSvyr}^{-1}$ (Organization for Economic Cooperation and Development, 1979)[14]. 


\subsection{External Hazard Index (Hex)}

The external hazard index is obtained from $R_{a e q}$ expression through the supposition that its maximum allowed value (equal to unity) corresponds to the upper limit of $\mathbf{R}_{\text {aeq }}$ (370 $B q \mathrm{~kg}^{-1}$ ). This index value must be less than unity in order to keep the radiation hazard insignificant; i.e., the radiation exposure due to the radioactivity from construction materials is limited to $1.0 \mathrm{mSv} \mathrm{y}^{-1}$, then the external hazard index $\left(\mathrm{H}_{\mathrm{ex}}\right)$ is given by the following equation:

$$
H_{e x}=\frac{C_{\mathrm{Ra}}}{370}+\frac{C_{7 h}}{259}+\frac{C_{K}}{4810} \leq 1
$$

Where $C_{\mathrm{Ra}}, C_{\mathrm{Th}}$ and $\mathrm{C}_{\mathrm{K}}$ are the concentration in $\left(B q \mathrm{Kg}^{-1}\right)$ of radium, thorium and potassium respectively. This index must be less than unity so that the annual effective dose due to radioactivity in the material will be less or equal to $1.5 \mathrm{mSvyr}^{-1}$. As indicated in Table 2, it appears that investigated materials meet this criterion.

Table 2. The Values of Radiation Hazard Parameters for Building Materials under Investigation

\begin{tabular}{|c|c|c|c|c|c|c|c|c|}
\hline Sample & Raeq & $\boldsymbol{H}_{e x}$ & $\begin{array}{c}\text { Gamma } \\
\text { index }\end{array}$ & $\begin{array}{c}\text { Dose rate } \\
(\dot{D})\end{array}$ & $\begin{array}{c}\text { Annual } \\
\text { Effective Dose }\end{array}$ & $\begin{array}{c}\text { Excess lifetime } \\
\text { cancer risk }\end{array}$ & \multicolumn{2}{|c|}{$\begin{array}{l}\text { Usability of a building } \\
\text { material factors }\end{array}$} \\
\hline name & $(B q / k g)$ & 1000 & $\mathrm{I}_{\mathrm{ex}}$ & $(n G y / h)$ & $D E(\mu S v)$ & $E L C R$ & $F 1$ & $F 2$ \\
\hline Soil(Assiut) & 136.2 & 0.37 & 0.48 & 114.8 & 0.06 & 0.20 & 0.40 & 39.7 \\
\hline Soil(Assiut) & 116.6 & 0.31 & 0.41 & 97.5 & 0.05 & 0.17 & 0.35 & 31.2 \\
\hline Soil(Assiut) & 127.4 & 0.34 & 0.45 & 107.7 & 0.05 & 0.18 & 0.38 & 35.0 \\
\hline Soil(Qena) & 157.9 & 0.43 & 0.56 & 132.1 & 0.06 & 0.23 & 0.47 & 37.5 \\
\hline Soil(Qena) & 135.3 & 0.37 & 0.48 & 113.8 & 0.06 & 0.20 & 0.41 & 32.5 \\
\hline Soil(Souhag) & 142.1 & 0.38 & 0.51 & 118.3 & 0.06 & 0.20 & 0.43 & 29.0 \\
\hline Soil(Souhag) & 143.5 & 0.39 & 0.51 & 121.0 & 0.06 & 0.21 & 0.43 & 37.5 \\
\hline Averange & 137.0 & 0.37 & 0.49 & 115.0 & 0.06 & 0.20 & 0.41 & 34.6 \\
\hline Range of values & 116.6-157.9 & $0.31-0.43$ & $0.41-0.56$ & 97.5-132.1 & $0.05-0.06$ & 29-39.7 & 0.35-0.47 & 29-39.7 \\
\hline Sand(Assiut) & 52.5 & 0.14 & 0.19 & 45.8 & 0.02 & 0.08 & 0.16 & 16.5 \\
\hline Sand(Assiut) & 53.6 & 0.14 & 0.19 & 46.4 & 0.02 & 0.08 & 0.16 & 17.7 \\
\hline Sand (Qena) & 82.1 & 0.22 & 0.29 & 70.7 & 0.03 & 0.12 & 0.24 & 28.7 \\
\hline Sand(Qena) & 80.9 & 0.22 & 0.29 & 69.2 & 0.03 & 0.12 & 0.24 & 23.5 \\
\hline Sand(Souhag) & 55.9 & 0.15 & 0.20 & 48.8 & 0.02 & 0.08 & 0.17 & 19.5 \\
\hline Sand(Souhag) & 61.5 & 0.17 & 0.22 & 53.5 & 0.03 & 0.09 & 0.19 & 18.7 \\
\hline Averange & 64.4 & 0.17 & 0.23 & 55.8 & 0.03 & 0.10 & 0.19 & 20.8 \\
\hline Range of values & $52.5-82.1$ & 0.14-0.22 & 0.19-0.29 & 45.8-70.7 & $0.02-0.03$ & $16.5-28.7$ & $0.16-0.47$ & $16.5-28.7$ \\
\hline Clay brick (Assiut) & 169.7 & 0.46 & 0.60 & 144.6 & 0.07 & 0.25 & 0.50 & 54.3 \\
\hline Clay brick (Assiut) & 203.8 & 0.55 & 0.72 & 173.9 & 0.09 & 0.30 & 0.61 & 65.0 \\
\hline Clay brick (Qena) & 203.8 & 0.55 & 0.73 & 173.5 & 0.09 & 0.30 & 0.61 & 59.6 \\
\hline Clay brick (Qena) & 143.3 & 0.39 & 0.51 & 120.2 & 0.06 & 0.21 & 0.43 & 36.0 \\
\hline Clay brick (Qena) & 121.2 & 0.33 & 0.43 & 101.1 & 0.05 & 0.17 & 0.36 & 29.3 \\
\hline Clay brick (Souhag) & 126.3 & 0.34 & 0.45 & 107.6 & 0.05 & 0.18 & 0.38 & 35.5 \\
\hline Clay brick (Souhag) & 201.2 & 0.54 & 0.71 & 168.5 & 0.08 & 0.29 & 0.60 & 51.7 \\
\hline Averange & 167.0 & 0.45 & 0.59 & 141.4 & 0.07 & 0.24 & 0.50 & 47.3 \\
\hline Range of values & $121.2-203.8$ & $0.33-0.55$ & $0.51-0.73$ & 101.1-173.9 & $0.05-0.09$ & 29.3-65 & $0.36-0.61$ & 29.3-65 \\
\hline Limestone (Assiut) & 106.8 & 0.29 & 0.38 & 89.2 & 0.04 & 0.15 & 0.32 & 30.0 \\
\hline
\end{tabular}




\begin{tabular}{|c|c|c|c|c|c|c|c|c|}
\hline Limestone (Assiut) & 118.1 & 0.32 & 0.42 & 98.8 & 0.05 & 0.17 & 0.35 & 35.3 \\
\hline Limestone (Qena) & 86.7 & 0.23 & 0.31 & 73.2 & 0.04 & 0.13 & 0.26 & 27.1 \\
\hline Limestone (Qena) & 103.1 & 0.28 & 0.36 & 84.3 & 0.04 & 0.14 & 0.31 & 23.0 \\
\hline Limestone (Souhag) & 105.6 & 0.29 & 0.37 & 88.1 & 0.04 & 0.15 & 0.31 & 33.5 \\
\hline Limestone (Souhag) & 151.1 & 0.41 & 0.53 & 122.7 & 0.06 & 0.21 & 0.45 & 31.6 \\
\hline Averange & 111.9 & 0.30 & 0.39 & 92.7 & 0.05 & 0.16 & 0.33 & 30.1 \\
\hline Range of values & $86.7-151.1$ & $0.23-0.41$ & $0.31-0.53$ & $73.2-122.7$ & 0.04-0.07 & 23-35.3 & $0.26-0.45$ & $23-35.3$ \\
\hline Gypsum(Assiut) & 125.5 & 0.34 & 0.44 & 103.9 & 0.05 & 0.18 & 0.37 & 40.1 \\
\hline Gypsum(Assiut) & 133.0 & 0.36 & 0.47 & 108.1 & 0.05 & 0.19 & 0.39 & 28.5 \\
\hline Gypsum(Qena) & 147.4 & 0.40 & 0.51 & 120.8 & 0.06 & 0.21 & 0.43 & 37.6 \\
\hline Gypsum(Qena) & 161.8 & 0.44 & 0.56 & 134.5 & 0.07 & 0.23 & 0.47 & 57.5 \\
\hline Gypsum(Souhag) & 154.0 & 0.42 & 0.54 & 127.1 & 0.06 & 0.22 & 0.45 & 46.4 \\
\hline Gypsum(Souhag) & 120.3 & 0.32 & 0.42 & 99.7 & 0.05 & 0.17 & 0.36 & 34.1 \\
\hline Averange & 140.3 & 0.38 & 0.49 & 115.7 & 0.06 & 0.20 & 0.41 & 40.7 \\
\hline Range of values & $120.3-161.8$ & $0.32-0.44$ & $0.42-0.56$ & $99.7-134.5$ & $0.05-0.07$ & $28.5-57.5$ & $0.36-0.47$ & $28.5-57.5$ \\
\hline Cement (Assiut) & 132.9 & 0.36 & 0.47 & 108.8 & 0.05 & 0.19 & 0.39 & 30.8 \\
\hline Cement (Assiut) & 115.4 & 0.31 & 0.41 & 95.2 & 0.05 & 0.16 & 0.34 & 29.0 \\
\hline Cement (Qena) & 125.3 & 0.34 & 0.44 & 103.3 & 0.05 & 0.18 & 0.37 & 33.5 \\
\hline Cement (Qena) & 97.3 & 0.26 & 0.34 & 81.1 & 0.04 & 0.14 & 0.29 & 29.8 \\
\hline Cement (Souhag) & 145.2 & 0.39 & 0.51 & 118.1 & 0.06 & 0.20 & 0.43 & 31.8 \\
\hline Cement (Souhag) & 148.3 & 0.40 & 0.52 & 122.7 & 0.06 & 0.21 & 0.44 & 44.2 \\
\hline Cement (Souhag) & 138.5 & 0.37 & 0.48 & 114.0 & 0.06 & 0.20 & 0.41 & 37.2 \\
\hline Averange & 129.0 & 0.35 & 0.45 & 106.2 & 0.05 & 0.18 & 0.38 & 33.76 \\
\hline Range of values & $97.3-148.3$ & $0.26-0.40$ & $0.34-0.52$ & 81.1-122.7 & 0.04-0.06 & $29-44.2$ & $0.29-0.44$ & $29.8-44.2$ \\
\hline
\end{tabular}

\subsection{Activity Concentration Index(I)}

Because more than one radionuclide contribute to the dose, it is practical to present investigation levels in the form of an activity concentration index, (I), or shortly, gamma index $(I)$, is defined in the following way:

$$
I=\frac{C_{\mathrm{Ra}}}{300}+\frac{C_{7 h}}{200}+\frac{C_{K}}{3000}
$$

Activity concentration index is derived to identify whether a dose criterion is met. The limit value that activity concentration index should not exceed depends on the dose criterion (EC 1999, 1999)[15]. The activity concentration index takes into account typical ways and quantities in which the material is used in a building D.Krsti'c et.al., 2007)[16]. The activity concentration index should be used only as a screening tool for identifying materials which might be of concern. In this paper, the Activity concentration index (I) was calculated and the results were listed in column 4, Table 2. Obtained values of $I$ ranged from 0.19 to 0.73 in studied samples.

\subsection{Dose Rate Indoor $(\dot{D})$}

Dose rate indoors are calculated according to (EC 1999, 1999)[15] for investigated samples as:

$$
\dot{D}=0.92 \mathrm{C}_{\mathrm{Ra}}+1.1 \mathrm{C}_{\mathrm{Th}}+0.08 \mathrm{C}_{\mathrm{k}}
$$


The specific dose rates (in units $\mathrm{nGy} \mathrm{h}{ }^{-1}$ per $\mathrm{Bq} \mathrm{kg}$ ) for ${ }^{226} \mathrm{Ra},{ }^{232} \mathrm{Th}$ and ${ }^{40} \mathrm{~K}$ are given for different materials. The results were listed also in Tables 2 and these values were used to calculate annual effective doses. The values of the absorbed dose rate in indoor air are in between (45.8 to 173.9$) \mathrm{nGy} \mathrm{h}^{-1}$.

\subsection{Annual Effective Dose Rate}

The annual effective dose, $D \mathrm{E}$, due to gamma radiation from building materials was calculated as:

$$
D \mathrm{E}=0.7 \mathrm{SvGy}^{-1} \cdot 7000 \mathrm{~h} \cdot \dot{D}
$$

Where $\dot{D}$ must be taken in $\mu G y h^{-1} ; 0.7 S v G y^{-1}$ is effective absorbed dose conversion factor, $7000 h$ is annual exposure time and $\dot{D}$. The resulting values of the annual effective dose rate have been listed in Table 2. We can find that, the lowest value of $D E$ is $0.02 \mathrm{mSv}$ while the highest is $0.09 \mathrm{mSv}$. According to (UNSCEAR, 2000) [2] the annual effective dose of these samples does not exceed the average worldwide exposure of 2.4 $\mathrm{mSvy}^{-1}$ due to natural sources.

\section{Comparison of Results with Similar Studies in Other Countries}

Our results for average specific activities of ${ }^{226} \mathrm{Ra},{ }^{232} \mathrm{Th}$ and ${ }^{40} \mathrm{~K}$ and radium equivalent activities Raeq in various types of building materials are compared in table 4 with the results for other countries.

\section{Table 3. Comparison of Activity and Radium Equivalent Activities $\mathbf{R a}_{\mathrm{eq}}$ in Building Materials used in Upper Egypt with those of other Countries}

\begin{tabular}{|c|c|c|c|c|c|c|}
\hline \multirow{2}{*}{$\begin{array}{l}\text { Materi } \\
\text { al }\end{array}$} & \multirow[t]{2}{*}{ Country } & \multicolumn{3}{|c|}{ Activity $\left(B q \mathrm{~kg}^{-1}\right)$} & \multirow[t]{2}{*}{$R a_{e q}$} & \multirow[t]{2}{*}{ Reference } \\
\hline & & ${ }^{226} \mathrm{Ra}$ & ${ }^{232} \mathrm{Th}$ & ${ }^{40} K$ & & \\
\hline \multirow{3}{*}{ Soil } & Turkay & $37 \pm 17$ & $40 \pm 18$ & $667 \pm 282$ & - & H. Taskin et al.2009 $9^{[16]}$ \\
\hline & Worldwide & 35 & 30 & 400 & - & $\operatorname{UNSCEAR}(2000)^{[2]}$ \\
\hline & Egypt & $34.6 \pm 1.7$ & $60.2 \pm 3$ & $212.3 \pm 10.3$ & 137 & This work \\
\hline \multirow{12}{*}{ Sand } & Algeria & $12 \pm 1$ & $7 \pm 1$ & $74 \pm 7$ & $28 \pm 7.1$ & $\begin{array}{c}\text { Amrani and Tahtat } \\
(2001)^{[17]}\end{array}$ \\
\hline & $\begin{array}{c}\text { Banglades } \\
h \\
\end{array}$ & $\begin{array}{c}14.53 \pm 8 . \\
2 \\
\end{array}$ & $34.78 \pm 2.4$ & $\begin{array}{c}303.11 \pm 141 . \\
91\end{array}$ & $\begin{array}{c}87.52 \pm 38 . \\
05 \\
\end{array}$ & Mantazul et al. $(1998)^{[18]}$ \\
\hline & Brazil & 10.2 & 12.6 & 51 & 34 & Malanca et al. $(1995)^{[19]}$ \\
\hline & Egypt & 9.2 & 3.3 & 47.3 & 16.6 & Sharaf et al. $(1999)^{[20]}$ \\
\hline & Greece & $18 \pm 7$ & $17 \pm 10$ & $367 \pm 204$ & - & Stoulos et al. $(2003)^{[21]}$ \\
\hline & India & 9.4 & 52.05 & 65.5 & 84.15 & Kumar et al. $(2003)^{(23)}$ \\
\hline & Kuwait & $7.9 \pm 0.7$ & $7.2 \pm 0.3$ & $360 \pm 14$ & 45.4 & $\begin{array}{c}\text { Bou-Rabee and Bem } \\
(1996)^{[24]}\end{array}$ \\
\hline & Malaysia & $60 \pm 3$ & $13 \pm 2$ & $750 \pm 53$ & $136 \pm 33$ & $\operatorname{Ibrahim}(1999)^{(25)}$ \\
\hline & Pakistan & 25.1 & 14.6 & 188.1 & 60.5 & $\begin{array}{c}\text { Ahmad and Hussein } \\
(1997)^{(26)}\end{array}$ \\
\hline & Zambia & $24 \pm 1$ & $26 \pm 2$ & $714 \pm 17$ & $117 \pm 12$ & Hayambu et al. (1995)[13] \\
\hline & Camiron & $14 \pm 1$ & $31 \pm 1$ & $586 \pm 13$ & 104.06 & Ngachina et.al. $(2006)^{(28)}$ \\
\hline & Egypt & $20.8 \pm 1$ & $22.5 \pm 1.2$ & $148.8 \pm 13.3$ & 64.4 & This work \\
\hline
\end{tabular}




\begin{tabular}{|c|c|c|c|c|c|c|}
\hline \multirow{18}{*}{$\begin{array}{l}\text { clay } \\
\text { brick }\end{array}$} & Algeria & $65 \pm 7$ & $51 \pm 5$ & $675 \pm 4$ & $190 \pm 9.5$ & $\begin{array}{l}\text { Amrani and Tahtat } \\
(2001)^{[17]}\end{array}$ \\
\hline & $\begin{array}{c}\text { Banglades } \\
h\end{array}$ & $\begin{array}{c}29.47 \pm 6 . \\
3\end{array}$ & $\begin{array}{c}52.5 \pm 12.1 \\
9\end{array}$ & $\begin{array}{c}292.25 \pm 43.6 \\
5\end{array}$ & $\begin{array}{c}127.14 \pm 9 . \\
85\end{array}$ & Mantazul et al. $(1998)^{[18]}$ \\
\hline & Brazil & $\begin{array}{c}46.8 \pm 19 \\
4\end{array}$ & $\begin{array}{c}119.9 \pm 110 \\
.6 \\
\end{array}$ & $322 \pm 152$ & $\begin{array}{c}247.7 \pm 170 \\
.3 \\
\end{array}$ & Malanca et al. $(1995)^{[19]}$ \\
\hline & Egypt & 24.5 & 24.4 & 227 & 77 & Sharaf et al. $(1999)^{[20]}$ \\
\hline & Greece & $35 \pm 11$ & $45 \pm 15$ & $710 \pm 165$ & - & Stoulos et al. $(2003)^{[1]}$ \\
\hline & India & 18.03 & 33.33 & 44.8 & 69.15 & Kumar et al. $(2003)^{[21]}$ \\
\hline & Malaysia & $241 \pm 3$ & $51 \pm 4$ & $7541 \pm 272$ & $895 \pm 107$ & $\operatorname{Ibrahim}(1999)^{[22]}$ \\
\hline & Egypt & $33 \pm 2.0$ & $37 \pm 1.7$ & $511 \pm 15.8$ & - & Ahmed $(2005)^{[23]}$ \\
\hline & Zambia & $32 \pm 2$ & $81 \pm 7$ & $412 \pm 19$ & $180 \pm 22$ & Hayambu et al. $(1995)^{[13]}$ \\
\hline & Camiron & $49.6 \pm 0.3$ & $91 \pm 2$ & $172 \pm 4$ & 193.34 & Ngachina et.al. $(2007)^{[24]}$ \\
\hline & Egypt & $47.3 \pm 2.4$ & $68.9 \pm 4.1$ & $275.7 \pm 12.3$ & 167 & This work \\
\hline & Brazil & 24.3 & 7 & 205 & - & Malanca et al. $(1995)^{[19]}$ \\
\hline & $\begin{array}{c}\text { Banglades } \\
\mathrm{h}\end{array}$ & 68 & 107 & 166 & 349 & Alam, M.(1999)[25] \\
\hline & Egypt & $20.4 \pm 2.8$ & $4.4 \pm 0.8$ & $19.3 \pm 2$ & 25.4 & Sharaf et al. $(1999)^{[20]}$ \\
\hline & Algeria & $16 \pm 3$ & $13 \pm 2$ & $36 \pm 3$ & $37 \pm 4.7$ & $\begin{array}{c}\text { Amrani and Tahtat } \\
(2001)^{[17]}\end{array}$ \\
\hline & Italy & 11 & $2.0 \pm 2.0$ & $22 \pm 3$ & $14 \pm 11$ & Rizzo, S. et al.(2001) ${ }^{[26]}$ \\
\hline & Egypt & $27.8 \pm 1.4$ & $46.6 \pm 2.3$ & $66 \pm 3.3$ & 79.85 & A. El-Taher $(2010)^{[27]}$ \\
\hline & Egypt & $30.1 \pm 2$ & $51.8 \pm 3.5$ & $101.1 \pm 10.9$ & 111.9 & This work \\
\hline \multirow{6}{*}{$\begin{array}{l}\text { Limeston } \\
\mathrm{e}\end{array}$} & Finland & 72 & 25 & - & - & NEA-OECD(1979) ${ }^{[14]}$ \\
\hline & UK & 22 & 7 & 141 & - & NEA-OECD $(1979)^{[14]}$ \\
\hline & Brazil & 6.3 & N.D. & 154 & 18.1 & Malanca et al. $(1995)^{[19]}$ \\
\hline & Italy & 6.0 & 2.0 & 32 & 12 & Rizzo, S. et al.(2001) ${ }^{[26]}$ \\
\hline & Egypt & $31.7 \pm 4.6$ & $55 \pm 2.7$ & $88.7 \pm 4.4$ & 116 & A. El-Taher $(2010)^{[27]}$ \\
\hline & Egypt & $40.7 \pm 2.4$ & $65.5 \pm 4.2$ & $77.9 \pm 9.6$ & 140.3 & This work \\
\hline \multirow{13}{*}{$\begin{array}{l}\text { Gypsu } \\
\text { m }\end{array}$} & Cameron & $27 \pm 4$ & $15 \pm 1$ & $277 \pm 16$ & 70 & Ngachina et.al. $(2007)^{[24]}$ \\
\hline & Finland & 44 & 26 & 241 & - & NEA-OECD $(1979)^{[14]}$ \\
\hline & Norway & 30 & 18 & 241 & - & 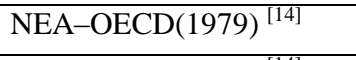 \\
\hline & Sweden & 55 & 47 & 241 & - & NEA-OECD $(1979)^{[14]}$ \\
\hline & $\mathrm{UK}$ & 22 & 18 & 155 & - & NEA-OECD $(1979)^{[14]}$ \\
\hline & Brazil & 61.7 & 58.5 & 564 & 188.8 & Malanca et al. $(1995)^{[19]}$ \\
\hline & $\begin{array}{c}\text { Banglades } \\
\mathrm{h}\end{array}$ & 29.7 & 54.3 & 523 & 148 & Alam, M.(1999) $)^{[25]}$ \\
\hline & Algeria & $41 \pm 7$ & $27 \pm 3$ & $422 \pm 3$ & $112 \pm 8.2$ & $\begin{array}{c}\text { Amrani and Tahtat } \\
(2001)^{[17]}\end{array}$ \\
\hline & Italy & $38 \pm 14$ & $22 \pm 14$ & $218 \pm 248$ & $92 \pm 60$ & Rizzo, S. et al.(2001) ${ }^{[26]}$ \\
\hline & Zambia & $23 \pm 2$ & $32 \pm 3$ & $134 \pm 13$ & $79 \pm 11$ & Hayambu et al. (1995)[13] \\
\hline & Egypt & $31.3 \pm 3.6$ & $11.1 \pm 1.1$ & $48.6 \pm 4$ & 50.9 & Sharaf et al. $(1999)^{[20]}$ \\
\hline & Egypt & $36.6 \pm 4.4$ & $43.2 \pm 2.2$ & $82 \pm 4.1$ & 103 & A. El-Taher $(2010)^{[27]}$ \\
\hline & Egypt & $33.8 \pm 3.1$ & $61.8 \pm 3.3$ & $89.0 \pm 5$ & 129 & this work \\
\hline
\end{tabular}

From the comparison of activity and radium equivalent activities $\mathrm{Ra}_{\mathrm{eq}}$ in building materials used in Upper Egypt with those of other countries in table 4, it is clear that our results are in average between other results. 


\section{Conclusions}

This study determined that the average natural radioactivity $\left({ }^{226} \mathrm{Ra},{ }^{232} \mathrm{Th}\right.$ and $\left.{ }^{40} \mathrm{~K}\right)$ concentrations and related radiation hazards in various building materials used in Egypt. All results were within the worldwide range. The radium equivalent activities obtained for the building materials under investigation were below the criterion limit of $\gamma$-radiation dose $\left(370 \mathrm{~Bq} \mathrm{~kg}^{-1}\right)$ adopted by the OECD 1979[14] criterion. The adsorbed dose rate in door was found to vary from 45.8 to $173.9 \mathrm{nGyh}^{-1}$ per $\mathrm{BqKg}^{-1}$, and the corresponding Annual Effective dose ranging is lower than the value $1.5 \mathrm{mSv} \mathrm{yr}^{-1}$ set in the OECD report [14]. In regard to the above results, Major radiation risk from examined materials comes from clay bricks and all the samples investigated can be safely used as building materials for dwelling constructions. It should be mentioned that anther building materials that were not studied here, so further investigations are needed to estimate the average exposure of people living in Upper Egypt dwellings.

\section{Acknowledgements}

This work was carried out using the nuclear analytical facilities at Physics Department, Faculty of Sciences, Al-Azhar University, Assiut, Egypt

\section{References}

[1] S. Stoulos, M. Manolopoulo and C. Papastefanou, "Environ. Radioact.”, vol. 69, pp. 225-240, (2003)

[2] UNSCEAR, United Nations Scientific Committee on the Effects of Atomic Radiation,. Sources, Effects and Risks of Ionizing Radiation. 2000 Report to the General Assembly with Annex B: Exposures from Natural Sources of Radiation. United Nations, New York,( 2000)

[3] UNSCEAR, United Nations Scientific Committee on the Effects of Atomic Radiation,. Sources, Effects and Risks of Ionizing Radiation. Report to the General Assembly with Annex B: Natural Sources of Radiation. United Nations, New York. (1977)

[4] Smith, Joshua. Borderland smuggling: Patriots, loyalists, and illicit trade in the Northeast, 1780-1820. Gainesville, FL: UPF. pp. passim. ISBN 0-8130-2986-4,(2007)

[5] American Society for Testing Materials (ASTM). Standard method for sampling surface soils for radionuclides. Report No. C (Philadelphia, PA: ASTM) pp. 983-998 (1983)

[6] American Society for Testing Materials (ASTM). Recommended practice for investigation and sampling soil and rock for engineering purposes. Report No. D (Philadelphia, PA: ASTM) Ann. Book of ASTM Standards (04.08) 420; pp. 109-113 (1986)

[7] GENIE-2000 Basic Spectroscopy (Standalone) V1.2A Copyright (c), Canberra Industries,(1997)

[8] Uosif, M. A. M. and El-Taher, A. Comparison of total experimental and theoretical absolute g-ray detection efficiencies of a cylindrical $\mathrm{NaI}(\mathrm{Tl})$ crystal. In: VII Radiation Physics and Protection Conference, Ismailia, Egypt, 27-30 November, (2004)

[9] Curve Expert 1.3: A comprehensive curve-fitting system for Windows Copyright (c) (1995-2003), Daniel Hyams.

[10] Reuss, U. and Westmeier, W. At. Data Nucl. Data Tables 29, (1983)

[11] Hamby, D. M. and Tynybekov, A. K. Environ. Monit. Assess. 73, 101-108 (2002)

[12] UNSCEAR, 1988. Sources, effects and risks of ionizing radiation. United Nations Scientific Committee on the effects of atomic radiation. Report to the General Assembly on the Effects of Atomic Radiation, United Nations, New York,(1988)

[13] Hayambu, P., Zaman, M.B., Lubaba, N.C.H., Munsanje, S.S., Muleya, D, J. Radioanal. Nucl. Chem. 199 (3), 229-238, (1995)

[14] NEA-OECD. Nuclear Energy Agency. Exposure to radiation from natural radioactivity in building materials. Report by NEA Group of Experts (Paris: OECD) Organization for Economic Cooperation and Development, Exposure to radiation from the natural radioactivity in building materials. OECD, Paris. (1979)

[15] EC 1999,. European Commission. Radiation Protection Unit, Radiological protection principles concerning the natural radioactivity of building materials. Radiat. Prot. 112,(1999)

[16] H. Taskin, M. Karavus, P. Ayb, A. Topuzoglu, S. Hidiroglu, G. Karahan Journal of Environmental Radioactivity 100 49-53,(2009).

[17] Amrani, D., Tahtat, M. Appl. Radiat. Isot. 54, 687-689, (2001).

[18] Mantazul, I., Chowdury, M.N., Alam, A.K.,. J. Radioanal. Nucl. Chem. 231 (1-2), 117-121,(1998).

[19] Malanca, A., Pessina, V., Dallara, G., Luce, N.C., Gaidol., L. Appl. Radiat. Isot. 46, 1387-1392, (1995).

[20] Sharaf, M., Mansy, M., El Sayed, A., Abbas, E., Radiat. Meas. 31, 491-495, (1999). 
[21] Kumar, A., Kumar, M., Singh, B., Singh, S., Radiat. Meas. 36, 465-469,( 2003).

[22] Ibrahim, N. J. Environ. Radioact. 43, 555-558, (1999).

[23] Ahmed, N.K., J. Environ. Radioact. 83, 91-99. (2005)

[24] Ngachin M., Garavaglia M., Giovani C.,. Kwato Njock M.G, Nourreddine A, Radia tion Measurements $42,61-67,(2007)$

[25] Alam, M. N., Chowdhury, M. I., Kamal, M., Ghose,S., Islam, M. N., Mustafa, M. N., Miah, M. M. H. and Ansary, M. M. J. Environ. Radioact. 46, 243-250 (1999).

[26] Rizzo, S., Brai, M., Basile, S., Bellia, S. and Hauser, S. Appl. Radiat. Isot. 55, 259-265(2001).

[27] A. El-Taher. Rad. Prot.Dos. Vol. 138, No. 2, pp. 166-173, (2010). 
International Journal of $u$ - and e- Service, Science and Technology Vol.7, No.2 (2014) 